\title{
EFEKTIFITAS SEKOLAH LAPANGAN GOOD AGRICULTURE PRACTICES (SLGAP) RIMPANG DALAM PENINGKATAN PRODUKSI DAN PENDAPATAN USAHATANI JAHE GAJAH (Zingiber officinalle Rosc.)
}

\author{
THE EFFECTIVENESS OF GOOD AGRICULTURAL \\ PRACTICES FIELD SCHOOL (SLGAP) OF RHIZOME IN \\ INCREASING PRODUCTION AND REVENUE OF ELEPHANT \\ GINGER (Zingiber officinalle Rosc.) FARMING
}

\author{
Agus Sukmadjaya \\ Balai Besar Pelatihan Pertanian Ketindan \\ Jalan Ketindan No 1 Lawang Malang 65215, Tlp/Fax: (0341) 426235/429725 \\ e-mail: asukma21@yahoo.com
}

\begin{abstract}
ABSTRAK
Kajian efektifitas SLGAP rimpang dalam peningkatan produksi dan pendapatan usahatani jahe gajah yang dilaksanakan pada SLGAP di Kecamatan Ngrayun Kabupaten Ponorogo. Tujuannya adalah untuk mengkaji efektifitas metode SLGAP terhadap persepsi perubahan perilaku dalam peningkatan pengetahuan, ketrampilan dan sikap, dan mengkaji perbedaan produksi dan pendapatan antara usahatani tanaman obat rimpang komoditas jahe yang dilaksanakan oleh petani alumnus SLGAP dan non SLGAP. Metode analisis data yang digunakan dalam kajian ini adalah analisis deskriptif, dan dengan menggunakan analisis Uji Beda (Uji t), untuk mengukur perbedaan produksi dan pendapatan antara petani alumnus SLGAP dan non SLGAP serta analisis regresi linier berganda (Multiple Regression Analysis) untuk mengukur faktor-faktor yang mempengaruhi produksi. Sampel dalam penelitian ini ditentukan dengan metode purposive masing-masing sebanyak 28 responden yang melakukan kegiatan usahatani jahe. Penentuan jumlah 28. Hasil kajian menunjukkan bahwa persepsi petani terhadap peningkatan pengetahuan dan ketrampilan sebanyak $86,90 \%$ responden menyatakan meningkat. Kemudian tingkat kepercayaan diri petani, sebanyak 79,80\% responden menyatakan dapat meningkatkan kepercayaan diri. Sedangkan terhadap penyampaian materi dan medode pelatihan sebanyak $72,60 \%$ responden, menyatakan bahwa materi pelatihan dalam SLGAP mudah dimengerti dan dipahami. Hasil uji beda (Uji t) terhadap produksi jehe antara petani peserta alumnus SLGAP dan non SLGAP menunjukkan bahwa tingkat produksi usahatani peserta SLGAP berbeda nyata dengan petani yang non SLGAP (selisih produksi sebesar $20,06 \mathrm{ton} / \mathrm{ha}-13,28 \mathrm{ton} / \mathrm{ha}=6,78 \mathrm{t} / \mathrm{ha}$ ). Sedangkan terhadap pendapatan usahatani antara petani peserta alumnus SLGAP dan non SLGAP menunjukkan tingkat pendapatan usahatani peserta SLGAP berbeda nyata dengan petani yang non SLGAP (selisih pendapatan sebesar Rp.46.646.250,00 - Rp.24.816.035,00 = Rp.21.830.214,00.
\end{abstract}

Kata Kunci : Peningkatan produksi, pendapatan dan perilaku petani.

\section{ABSTRACT}

The SLGAP of rizhome effectiveness study in increasing production and income of elephant ginger farming carried out at SLGAP in Ngrayun District, Ponorogo Regency. The aim is to assess the effectiveness of the SLGAP method on perceptions of behavior change in increasing knowledge, skills and attitudes, and assessing production and income between farming of rhizome medicinal plants of ginger 
commodities carried out by farmers participating in the SLGAP and non SLGAP alumni. The data analysis method used in this study is descriptive analysis, and by using the Difference Test ( $t$ test), to measure the difference in production and income between SLGAP and non SLGAP alumni farmers and multiple Regression Analysis to measure factors that affect production. The sample in this study was determined by purposive method, each of the 28 respondents who did ginger farming activities. Determination of the number 28. The results of the study showed that the perceptions of farmers on increasing knowledge and skills as much as $86.90 \%$ of respondents stated that they had increased. Then the level of confidence of farmers, as much as $79.80 \%$ of respondents said they could increase selfconfidence. While for the delivery of material and training method as much as $72.60 \%$ of respondents, stated that the training material in SLGAP was easily understood and understood. The results of the different tests ( $t$ test) on the production of jehe between farmers participating in the SLGAP and non SLGAP alumni showed that the production level of SLGAP participant farms was significantly different from non SLGAP farmers (production difference was 20.06 tons / ha - 13.28 tons / ha $=6.78 \mathrm{t} / \mathrm{ha}$ ). Whereas the farming income between farmers participating in SLGAP and non SLGAP alumni showed that the level of farm income of SLGAP participants was significantly different from those of non SLGAP farmers (income difference of Rp.46,646,250.00 - Rp.24,816,035.00 $=R p .21,830,214,00$.

Keywords: Increased production, income and behavior of farmers.

\section{PENDAHULUAN}

Jahe (Zingiber officinale Rosc.) merupakan salah satu komoditas ekspor tanaman obat Indonesia, disamping itu juga menjadi bahan baku utama obat tradisional maupun fitofarmaka. Permintaan terhadap produk jahe terus meningkat seiring dengan naiknya permintaan dunia serta berkembangnya industri makanan, minuman dan industri jamu di dalam negeri yang menggunakan bahan baku jahe.

Indonesia pernah menguasai pangsa pasar jahe dunia dengan nilai ekspor terbesar pada tahun 1990 sampai 1993 namun sejak tahun 1994 sampai tahun 2007 posisi ini digantikan Cina dan negara pengekspor jahe terbesar lainnya seperti Belanda, Thailand, India, dan Brazil diurutan kelima (Frans Hero Kamsia Purba, 2012). Data Badan Pusat Statistik (BPS) selama lima tahun terakhir 2007 sampai 2011 menunjukkan rata-rata penurunan ekpor jahe sebesar $64 \%$ per tahun, dan pada tahun 2009, Indonesia hanya menempati posisi ke-14 dengan nilai ekspor sebesar US\$ 1.635.026. Pada tahun 2011 ekspor jahe masih rendah hanya mencapai 1.176 ton dengan nilai nominal US \$ 1.209.000 ( Sumber Data BPS diolah, 2012). Hal tersebut disebabkan karena baik produktivitas maupun mutunya tidak memenuhi standar (Otih, Bermawie dan Raharjo, 2009).

Rendahnya produksi, produktivitas serta mutu produk tanaman obat rimpang, terutama jahe disebabkan karena petani belum melakukan pengelolaan usahatani secara baik, belum menerapkan teknologi anjuran. Ada sebagian petani yang hanya tergantung pada alam, tetapi ada yang berlebihan dalam penggunaan pestisida. Kondisi ini menyebabkan tingginya tingkat residu pestisida yang pada akhirnya mengakibatkan tidak aman dikonsumsi serta pencemaran lingkungan. Oleh karenanya perlu ditangani lebih terarah untuk dapat menghasilkan produksi dan mutu hasil yang tinggi serta ramah lingkungan. Untuk maksud tersebut usaha tani harus menggunakan teknologi maju dan dikelola secara professional dan efektif sejalan dengan kaidah Good Agriculture Practices (GAP).

Menghadapi tantangan dan tuntutan tersebut, perlu adanya pembinaan melalui pelatihan petani yang mengusahakan tanaman rimpang dalam penerapan budidaya yang baik (GAP). Sehubungan dengan telah berkembangnya sentra - sentra produksi tanaman obat rimpang pada beberapa daerah, maka penerapan GAP tersebut harus diikuti dengan Standar Operasional Prosedur 
(SOP), setiap komoditas yang bersifat spesifik lokasi. Penerapan GAP perlu dilengkapi dengan tersedianya SOP budidaya komoditas sebagai panduan petani dalam melakukan usahatani di lahan masingmasing.

Penerapan budidaya berdasarkan GAP tersebut dilakukan melalui metode siklus pembelajaran petani secara langsung di lahan usahataninya dengan konsep Sekolah Lapangan (SL). Istilah "Sekolah Lapangan" pertama kali digunakan dalam Program Nasional Pengendalian Hama Terpadu (PHT), yang selanjutnya dikenal dengan "SLPHT". Pendekatan sekolah lapangan ini dikembangkan mulai tahun 1989 oleh Petugas Departemen Pertanian yang dilatih menjadi Pemandu Lapangan, bekerja sama dengan tim bantuan teknis dari FAO, dalam rangka Program Nasional PHT.

Sekolah Lapangan yang selanjutnya disingkat SL adalah suatu model pelatihan yang dilaksanakan secara bertahap dan berkesinambungan untuk mempercepat proses peningkatan kompetensi sasaran; dimana proses berlatih melatih dilaksanakan melalui kegiatan belajar sambil mengerjakan dan belajar untuk menemukan/memecahkan masalah sendiri, dengan berazas kemitraan antara pelatih dan peserta. (Deptan Badan Pengembangan SDM Pertanian, 2007).

Sekolah Lapangan GAP (SLGAP) merupakan salah satu pendekatan dalam meningkatkan pengetahuan, kemampuan dan ketrampilan petani tentang prinsip GAP melalui pola pembelajaran lewat pengalaman dengan menggunakan lahan sebagai tempat belajar. Melalui sekolah lapangan yang dilakukan setiap minggu sepanjang periode tanam, diharapkan petani dapat memantau pertanaman secara teratur sekaligus dapat mengkaji dan membahasnya sehingga menjadi ahli dan dapat mengambil keputusan sendiri.

Penerapan budidaya yang baik (Good Agriculture Practices) adalah upaya untuk menghasilkan produk bermutu, aman dikonsumsi serta mencakup penerapan teknologi ramah lingkungan yang telah

3 | Jurnal Agriekstensia Vo. 18 No. 1 Juli 2019 ditetapkan melalui Peraturan Menteri Pertanian Nomor 48/Permentan/OT.140/10/2009.

Kabupaten Ponorogo sebagai salah satu sentra produksi rimpang terutama jahe, dengan luas tanam seluas 730 ha, dengan produktivitas 12,61 ton/ha (Dinas Pertanian Kabupaten Ponorogo, 2012), merupakan kabupaten sentra di Provinsi Jawa Timur yang telah mempunyai SOP yang disusun pada tahun 2009. Serta telah melaksanakan SLGAP rimpang, khususnya pada komoditas jahe gajah, pada 2 (dua) kelompok tani di Kecamatan Ngrayun, yaitu pada tahun 2010 dan musim tanam 2011 - 2012. Untuk melihat sampai sejauhmana dampak SLGAP rimpang khususnya komoditas jahe terhadap produksi dan pendapatan usaha tani, maka Kabupaten Ponorogo Kecamatan Ngrayun dipilih sebagai obyek penelitian.

\section{METODE PENELITIAN}

Kajian ini dilakukan di Kecamatan Ngrayun Kabupaten Ponorogo pada SLGAP tahun 2012. Lokasi pengujian ini dipilih secara purposif dengan pertimbangan merupakan salah satu tempat dilakukannya SLGAP Rimpang. Sampel dalam penelitian ini ditentukan dengan metode purposive (sengaja) dengan pertimbangan bahwa petani sebagai sampel dalam penelitian yang dilakukan di Kecamatan Ngrayun mempunyai perilaku cenderung homogen. Sampel dalam penelitian adalah petani alumnus SLGAP dan petani non SLGAP masing-masing sebanyak 28 responden yang melakukan kegiatan usahatani tanaman obat rimpang khusus komoditas jahe, yang ditentukan secara sengaja (purposive). Penentuan jumlah 28 responden ini diangap bahwa sample sudah mampu mewakili jumlah populasi petani di Kecamatan Ngrayun.

Macam data yang diperlukan dalam penelitian ini adalah data primer dan data sekunder. Data primer dikumpulkan melalui teknik wawancara dan atas dasar kuesioner 
yang telah disiapkan kepada petani responden yaitu petani tanaman jahe alumnus SLGAP dan petani Non SLGAP. Data sekunder diperoleh melalui studi pustaka dan juga dari beberapa instansi pemerintah yang terkait yaitu dari Dinas Pertanian Provinsi Jawa Timur dan Dinas Pertanian Kabupaten Ponorogo.

Kajian ini menduga (1) persepsi petani terhadap perubahan perilaku dalam peningkatan pengetahuan, ketrampilan dan sikap, (2) terdapat perbedaan produksi dan pendapatan antara usahatani jahe gajah yang dilaksanakan oleh petani peserta alumnus SLGAP dan non SLGAP. Untuk menguji hipotesa pertama dilakukan dengan statistik deskriptif yang berfungsi untuk mendeskripsikan atau memberi gambaran terhadap obyek yang diteliti melalui data, sampel dan populasi sebagaimana adanya tanpa melakukan analisis dan membuat kesimpulan yang berlaku untuk umum, Sedangkan untuk menguji hipotesa kedua dengan Uji Beda produksi dan pendapatan antara petani tanaman jahe alumnus SLGAP dan non SLGAP yaitu dengan menggunakan analisis Uji Beda (Uji t).

\section{HASIL DAN PEMBAHASAN}

\section{Persepsi Petani Terhadap Perubahan Perilaku Dalam Pelaksanaan SLGAP.}

Persepsi petani merupakan tanggapan dan kehendak petani dan sekaligus gambaran perilaku petani dalam melaksanakan kegiatan SLGAP, melalui penerapan GAP dan SOP budidaya tanaman jahe. Persepsi petani terhadap perubahan perilaku dalam pelaksanaan kegiatan SLGAP adalah sebagai berikut :

\section{a. Peningkatan Pengetahuan dan Keterampilan.}

Sebagian besar responden $(86,90$ $\%$ ) menyatakan bahwa pelatihan dengan metode SLGAP dapat meningkatkan pengetahuan dan keterampilan dalam hal pengelolaan usaha tani dan teknik budidaya yang baik yang berimplikasi pada peningkatan produksi dan pendapatan usaha tani. Hal tersebut menunjukkan bahwa penerapan SOP pada petani alumnus SLGAP lebih optimal dibanding non SLGAP.

Akan tetapi masih ada petani responden terutama petani non SLGAP sebesar $13,10 \%$ yang menyatakan pelatihan dengan menode SLGAP, masih belum dapat meningkatkan kemampuan terhadap upaya peningkatan produksi. Dengan alasan bahwa kegiatan usahatani akan dapat berjalan sesuai dengan SOP, jika penyediaan faktorfaktor produksi seperti penyediaan benih unggul, penyediaan pupuk baik pupuk organik maupun pupuk buatan serta biaya yang dimiliki oleh petani cukup memadai. Sementara ini penyediaan benih unggul rimpang masih terbatas, penyediaan pupuk organik maupun buatan juga masih ada keterbatasan, sedangkan disisi lain tingkat kemampuan modal yang dimiliki petani masih relatif rendah.

\section{b. Tingkat Kepercayaan Diri Peserta.}

Sebagian besar responden $(79,80 \%)$ menyatakan bahwa kegiatan SLGAP terhadap tingkat kepercayaan diri petani, dalam hal mengatasi berbagai permasalahan terutama teknik budidaya di lapangan serta keberhasilan pencapaian target setelah mempelajari materi pelatihan. Hal tersebut menunjukkan adanya perubahan perilaku atau perubahan sikap dari petani terutama petani peserta SLGAP. Dengan pelatihan melalui pola SLGAP meyakinkan dapat kepercayaan diri petani, bahwa SOP budidaya jahe gajah dapat diterapkan di Kecamatan Ngrayun Kabupaten Ponorogo dengan baik.

Sedangkan $\quad 20,20 \%$ petani responden terutama pada petani non SLGAP, menyatakan bahwa proses pelaksanaan pelatihan dengan metoda SLGAP, masih kurang meyakinkan terhadap tingkat kepercayaan diri peserta. Dengan alasan belum mengalami proses pembelajaran dalam hal penerapan GAP/SOP budidaya rimpang, masih belum memahami tahapan pelaksanaan SOP budidaya rimpang, serta 
mereka masih punya keyakinan bahwa faktor alam sangat menentukan dalam keberhasilan usahatani.

\section{c. Materi dan Metode Pelatihan}

Sebagian besar responden $(72,60 \%)$, menyatakan bahwa materi pelatihan dalam SLGAP, mudah dimengerti dan dipahami dalam hal meningkatkan kemampuan bidang operasional serta metode simulasi praktek kerja di lapangan sangat bermanfaat dan membantu pelaksanaan pekerjaan. Hal tersebut menunjukkan bahwa proses pelatihan melalui metode SLGAP sangat efektif dalam memberikan pemahaman dan kemampuan kepada petani peserta.

Akan tetapi masih ada juga petani responden, sebesar 27,40 \% menyatakan bahwa materi dan metode pelaksanaan SLGAP, masih kurang memahami. Kondisi tersebut tidak terlepas dari tingkat pendidikan petani bahwa tingkat pendidikan akan mempengaruhi sikap, kemampuan dan tingkah laku dalam menghadapi suatu permasalahan dan pengambilan keputusan.

\section{Perbedaan Produksi dan Pendapatan Usahatani Jahe antara Petani Peserta SLGAP dan Petani Non SLGAP}

Untuk mengetahui perbedaan tingkat produksi dan pendapatan dari usahatani jahe gajah antara petani yang mengikuti SLGAP dengan petani yang tidak mengikuti SLGAP digunakan uji hipotesis yaitu uji $\mathrm{t}$ dua sampel bebas (independent sample test). Lebih jelasnya perbedaan produksi dan pendapatan usahatani jahe gajah antara petani peserta SLGAP dan Non SLGAP seperti pada tabel berikut :

\section{Tabel 1. Hasil Analisis Uji-t Perbandingan Produksi dan Pendapatan Usahatani Jahe Gajah Pada Petani Peserta SLGAP dan Non SLGAP}

\begin{tabular}{llrlrrr}
\hline & \multicolumn{1}{c}{ Status } & $\begin{array}{c}\text { Rata2 Produksi } \\
\text { \&Pendapatan }\end{array}$ & F & Taraf Sig. & t & Taraf Sign. \\
\hline \multirow{2}{*}{ Produksi } & Petani SLGAP & 20.0643 & .252 & .618 & 12.688 & .000 \\
& Petani Non SLGAP & 13.2839 & & 12.688 & .000 \\
\hline \multirow{2}{*}{ Pendapatan } & Petani SLGAP & 46.646 .250 .00 & 2.229 & .141 & 12.088 & .000 \\
& Petani Non SLGAP & 24.816 .035 .71 & & 12.088 & .000 \\
\cline { 2 - 6 }
\end{tabular}

Berdasarkan dari Tabel 1. diatas diketahui rata-rata produksi usahatani jahe gajah dari petani peserta SLGAP sebesar 20,06 ton/ha. Sedangkan rata-rata petani non SLGAP sebesar 13,28 ton/ha. Dari dua analisis ini dapat diketahui rata-rata produksi usahatani jahe gajah petani peserta SLGAP lebih besar dari pada petani yang non SLGAP terdapat selisih 6,78 ton/ha.

Sedangkan ditinjau dari tingkat pendapatan bersih (keuntungan) usahatani jahe gajah, rata-rata petani peserta SLGAP sebesar Rp. 46.646.250,00. Sedangkan, ratarata petani non SLGAP sebesar Rp. 24.816.035,00.

Dari dua hasil analisis ini dapat diketahui rata-rata pendapatan usahatani, petani peserta SLGAP lebih besar dari pada petani Non SLGAP, terdapat selisih Rp. 21.830.214,00.

Dikarenakan pernyataan Ho dan $\mathrm{Hi}$ mengadung pertidaksamaan maka diuji dengan dua sisi antara produksi usahatani Jahe Gajah petani peserta SLGAP dan non SLGAP. Diketahui nilai probabilitas sebesar 0,00 . karena probabilitas kurang dari 0,05 maka Ho ditolak atau Hi diterima, atau jika dilihat dari nilai $t_{\text {hitung }}$ yaitu sebesar 12,688 lebih besar dari nilai $t_{\text {tabel }}$ yaitu sebesar 2,052, yang diartikan kedua rata-rata tingkat produksi usahatani peserta SLGAP berbeda nyata dengan petani yang non SLGAP.

Selanjutnya dari tingkat pendapatan usahatani jahe gajah juga diketahui nilai probabilitas 0,00 atau probabilitas kurang dari 0,05 , maka Ho ditolak atau Hi diterima, 
atau jika dilihat dari nilai $t_{\text {hitung }}$ yaitu sebesar 12,088 lebih besar dari nilai $t_{\text {tabel }}$ yaitu sebesar 2,052 yang diartikan kedua rata-rata tingkat pendapatan usahatani petani peserta SLGAP berbeda nyata dengan petani yang non SLGAP.

Perbedaan produksi dan pendapatan usahatani tersebut, terjadi karena penggunaan dari faktor-faktor produksi yaitu lahan, benih, pupuk dan penggunaan tenaga kerja yang digunakan dalam kegiatan proses produksi mulai pengolahan tanah sampai dengan panen berbeda antara petani peserta SLGAP dan non SLGAP, yang dapat dilihat dari masing-masing faktor produksi seperti pada tabel berikut :

Tabel 2. Biaya Benih, Pupuk dan Tenaga Kerja yang Dikeluarkan untuk Usahatani Jahe Gajah per Hektar Dari Petani Peserta SLGAP dan Non SLGAP

\begin{tabular}{llrrr}
\hline No & \multicolumn{1}{c}{ URAIAN } & PETANI & \multicolumn{1}{c}{ PETANI Non } & \multicolumn{1}{c}{ SELISIH } \\
& & \multicolumn{1}{c}{ SLGAP } & \multicolumn{1}{c}{ SLGAP } & \\
\hline 1. & Biaya Benih $(\mathrm{Rp} / \mathrm{Ha})$ & 28.247 .698 & 16.203 .569 & 12.044 .129 \\
2 & Biaya Pupuk (Rp/Ha) & 9.894 .049 & 9.256 .729 & 637.320 \\
3 & Biaya Tenaga Kerja (Rp/Ha) & 10.489 .500 & 10.034 .240 & 455.260 \\
& JUMLAH USAHATANI & $\mathbf{4 8 . 6 3 1 . 2 4 7}$ & $\mathbf{3 5 . 4 9 4 . 5 3 8}$ & $\mathbf{1 3 . 1 3 6 . 7 0 9}$ \\
& (Rp/Ha) & & & \\
\hline
\end{tabular}

Pada tabel 2. dapat dilihat bahwa penggunaan faktor-faktor produksi yang digunakan dalam kegiatan usahatani jahe gajah dari petani peserta SLGAP sebesar Rp.48.631.247 per hektar, lebih besar dibanding dengan penggunaan faktor-faktor produksi yang digunakan dalam kegiatan usahatani jahe gajah petani non SLGAP, sebesar Rp.35.494.538 per hektar, ada selisih Rp.13.136.709 per hektar. Kondisi tersebut menunjukkan bahwa penggunaan faktorfaktor produksi dari petani peserta SLGAP lebih optimal, atau dapat diartikan implementasi SOP melalui metode SLGAP telah dilakukan dengan baik, sehingga produksi yang dihasilkan hampir mencapai produksi optimal. Sedangkan produksi optimal jahe putih besar (Cimanggu-1) ratarata bisa menghasilkan 27 ton/ha rimpang segar (Otih Rostiana, Rosita dan Mono Rahardjo, 2009).

Dengan demikian penggunaan faktor-faktor produksi yang optimal, seperti penggunaan benih yang bermutu dan berlabel, penggunaan pupuk yang berimbang, serta pemanfaatan sumber tenaga kerja sesuai dengan kebutuhan dalam pengelolaan sistem budidaya yang tepat mulai dengan pengolahan tanah, pemeliharaan sampai dengan pemanenan. akan dapat meningkatkan produksi dan menghasilkan pendapatan usahatani yang diterima petani lebih besar.

\section{KESIMPULAN}

Berdasarkan data hasil dan pembahasan dapat disimpulkan bahwa pelatihan dengan metode SLGAP terhadap persepsi perubahan perilaku dalam peningkatan pengetahuan, ketrampilan dan sikap sangat efektif. Hal ini ditunjukkan dengan hasil analisis data bahwa : a) Persepsi petani terhadap peningkatan pengetahuan dan ketrampilan sebanyak $86,90 \%$ responden menyatakan meningkat. b) tingkat kepercayaan diri petani, sebanyak $79,80 \%$ responden menyatakan dapat meningkatkan kepercayaan diri dan c) terhadap penyampaian materi dan medode pelatihan sebanyak $72,60 \%$ responden menyatakan bahwa materi pelatihan dalam SLGAP, mudah dimengerti dan dipahami. Lebih lanjut hasil kajian terhadap produksi jehe antara petani peserta alumnus SLGAP dan non SLGAP menunjukkan bahwa tingkat produksi usahatani peserta SLGAP berbeda nyata dengan petani yang 
non SLGAP (selisih produksi sebesar 20,06 ton/ha - 13,28 ton/ha $=6,78 \mathrm{t} / \mathrm{ha}$ ). Sedangkan terhadap pendapatan usahatani antara petani peserta alumnus SLGAP dan non SLGAP menunjukkan tingkat pendapatan usahatani peserta SLGAP berbeda nyata dengan petani yang non SLGAP (selisih pendapatan sebesar Rp.46.646.250,00 - Rp.24.816.035,00 = Rp.21.830.214,00.

Dengan demikian pelatihan dengan metode SLGAP ini, akan membentuk perubahan pola pikir dan perilaku petani, hal ini berimplikasi pada peningkatan produksi dan pendapatan usahatani komoditas jahe gajah di Kecamatan Ngrayun kabupaten Ponorogo.

\section{DAFTAR PUSTAKA}

Afandi. M, 2006. Dampak Sekolah Lapangan Pengendalian Hama Terpadu Terhadap Peningkatan Produksi dan Pendapatan UsahanTani Padi (Studi Kasus di Kecamatan Cerme, Kabupaten Gresik). Tesis Pasca sarjana UPN 'Veteran" Jawa Timur Surabaya.

Agus dan Pudji, 2009. Analisis Dampak Sekolah Lapang Pengelolaan Terpadu Kedelai Terhadap Peningkatan Produktivitas dan Pendapatan Usahatani di Jawa Timur (Kasus di Kabupaten Jember dan Bojonegoro).

Departemen Pertanian. Badan Pengembangan SDM Pertanian. 2007. Pedoman Umum Penyelenggaraan Sekolah Lapangan.

Departemen Pertanian. Dirjen Hortikultura. Direktorat Budidaya tanaman Sayuran Dan Biofarmaka. 2008. Budidaya Jahe (Zingeber officinale) Standar Operasional Prosedur.
Diperta Provinsi Jawa Timur, 2011. Laporan Tahunan Dinas Pertanian Provinsi Jatim Tahun 2011.

Emory, William C. and Cooper Donald R. 1991. Business Research Method. Fourth Edition. Richard D Irving Inc. New York.

Frans Hero Kamsia Purba, 2012. http://heropurba.blogspot.com/2012 $/ 10 /$ potensi-jahe-dalam-peluangusaha.html

Gujarati, D N. 1995. Basic Econometrics. Third Edition. McGraw-Hill, Singapore.

Hair J. F., Anderson R. E., Tatham R. L., and Black W. C. 1992. Multivariate Data Analysis. McMillan Publising Company. New York.

Otih Rostiana, Rosita, dan Raharjo. 2009. Standar Prosedur Operasional Budidaya Jahe, Kencur, Kunyit dan Temulawak. Badan Penelitian dan Pengembangan Pertanian. Balai Penelitian Tanaman Obat dan Aromatik.

Santoso Singgih, 2001. SPSS Statistik Parametrik. Elex Media Komputindo, Jakarta

Sugiyono, 2012. Metode Penelitian Bisnis. Cetakan ke 16 Penerbit Alfabeta Bandung. 